\title{
UV-C radiation on fresh fig quality
}

\author{
Franciane Colares Souza Usberti* (i), Antonio Carlos de Oliveira Ferraz ${ }^{(0)}$
}

Universidade Estadual de Campinas/FEAGRI - Conselho Integrado de Tecnologia de Processos, Av. Cândido Rondon, 501 - Barão Geraldo - 13083-875 - Campinas, SP - Brasil.

*Corresponding author <fran2606@unicamp.br>

Edited by: Luís Guilherme de Lima Ferreira Guido

Received June 18, 2019

Accepted October 10, 2019
ABSTRACT: Sanitization using chemical agents to reduce the microbiological load on the surface of agricultural products have the drawback of leaving residues. Conversely, physical treatments, such as ultraviolet radiation C (UV-C), are residue-free, non-toxic and environmentally friendly. Ripe figs are perishable, exhibiting an epidermis with low resistance to mechanical treatment, high water content and the ostiole, which is an open door that expedites undesirable microorganism penetration. In this study, the effect of different energy levels of UV-C radiation on the appearance and physico-chemical properties of the figs when stored at $10{ }^{\circ} \mathrm{C}$ and 20 ${ }^{\circ} \mathrm{C}$ was evaluated focusing on the technological parameters of the application of radiation. The energy levels of radiation applied were $0.00,0.71,1.32,2.64$ and $4.01 \mathrm{~kJ} \mathrm{~m}^{-2}$ and they showed neither acceleration nor delay effects on fig ripening. Figs exposed to the radiation energy at $0.71,1.32,2.64$ and $4.01 \mathrm{~kJ} \mathrm{~m}^{-2}$ showed a lower incidence of rot at the same temperature, but the figs exposed to the highest radiation, $4.01 \mathrm{~kJ} \mathrm{~m}^{-2}$, showed more wilting and stains, which significantly impaired their appearance. UV-C radiation reduces the development of rotting, providing evidence of its potential in the postharvest processing of ripe figs. However, radiation levels should be limited to avoid undesirable epidermis stains.

Keywords: Ficus carica L., irradiation, postharvest conservation, micro-organism inactivation

\section{Introduction}

There is a growing awareness of health and nutritious diets rich in vitamin $\mathrm{C}$, phenolic compounds, flavonoids (Tureck et al., 2017; Klinder et al., 2016), and increased fresh fruit and vegetable consumption. However, the emergence of the potential associated with pathological microorganisms in foods consumed in natura cannot be ignored (Wadamori et al., 2017; Zhu et al., 2017). Sanitization using chemical agents to reduce the surface microbiological load in agricultural products (Bermúdez-Aguirre and Barbosa-Cánovas, 2013), have the drawback of leaving residue (Coelho et al., 2015). Conversely, sanitization using the so-called physical treatments are residue-free, safe, non-toxic and environmentally friendly (São José et al., 2014). For this reason, the effect of non-thermal physical treatments such as ozonization, ultraviolet radiation (UV-C) and modified atmosphere have recently become subjects for investigation (Van Hung et al., 2011; Ge et al., 2013; Savi et al., 2014; Aday et al., 2013; Bermúdez-Aguirre and Barbosa-Cánovas, 2013; São José et al., 2014).

Ripe figs (Ficus carica L.) are perishable, exhibiting low resistance to mechanical treatment in the epidermis, high water content and the ostiole, expediting undesirable microorganism penetration. Figs are classified as nonclimacteric (Ryall and Pentzer, 1982); however, they have an increase in ethylene production and respiratory activity at certain stages of their development. Several studies have shown that the use of UV-C irradiation can be a potential treatment that will enhance the postharvest life of fruit and vegetables. The use of this technology can delay ripening, retard microbial growth and increase fruit firmness (Pombo et al., 2009; Ding and Yap, 2014; Ding et al., 2015). The main microbial inactivation mechanism uses photoproducts that can interrupt both transcription and DNA translation (Franz et al., 2009), and could be lethal to micro-organisms (Yaun et al., 2004). Characteristically, the penetration depth of UV-C light is close to the incident surface, facilitating an eminently superficial interaction. Manzocco et al. (2011) estimated to be $0.2 \mathrm{~mm}$ the UV-C radiation penetration depth in apple pulp.

In this study the effect of ultraviolet C (UV-C) radiation on fresh figs was investigated. Considering the limited information on ripe figs, the effect of the different energy levels of continuous UV-C radiation on their appearance and physico-chemical properties, when stored at temperatures of $10{ }^{\circ} \mathrm{C}$ and $20^{\circ} \mathrm{C}$, were investigated focusing on the determination of the technological parameters supporting the application of radiation.

\section{Materials and Methods}

Ripe 'Roxo de Valinhos' figs (Ficus carica L.) weighing between $50 \mathrm{~g}$ and $70 \mathrm{~g}$, free of visible physical and microbiological damage, acquired directly from the producers in the city of Campinas, SP, Brazil $\left(22^{\circ} 59^{\prime} 33.6^{\prime \prime}\right.$ $\mathrm{S}, 47^{\circ} 05^{\prime} 05.1^{\prime \prime} \mathrm{W}$, altitude of $685 \mathrm{~m}$; average day and night temperature $20^{\circ} \mathrm{C}$ and $34^{\circ} \mathrm{C}$, respectively), were harvested in the morning, transported to the laboratory and kept at an ambient temperature of $20^{\circ} \mathrm{C}$ were used.

From the harvested lot, figs with approximately half of their surface a purplish color were selected. The radiation chamber used, which was built of plywood, measured $1000 \times 1000 \times 600 \mathrm{~mm}$ and was coated internally with aluminum foil, accommodated twelve UV lamps ( $30 \mathrm{~W}$ ), $894.6 \mathrm{~mm}$ long and $28 \mathrm{~mm}$ in diameter, equally distributed over the lower and upper 
parts (Figure 1). The lamps, emitting short-wave UV peak radiation at $253.7 \mathrm{~nm}$ (UV-C) were coated with special glass that retains radiation and produces ozone (185 nm). The figs were placed in a resting position (Figure 1) on a metal screen with a square mesh of $10 \mathrm{~mm}$, without touching each other, at a distance of $220 \mathrm{~mm}$ from the upper and lower lamps. In this configuration, the total fluence rate of UV-C radiation on the metal screen surfaces, considering the lower and upper radiation levels, was $0.044 \mathrm{~W} \mathrm{~m}^{-2}$. This value corresponds to the average of nine measurements on the metallic screen, keeping the surface of the radiometer sensor (Optometer Optical Power Meter Newport, model 1830-C, $0.1 \mathrm{pW}$ ) parallel to the plane of the lamps. The amount of radiation calculated took into account the exposure time, and resulted in values of $0.00,0.71,1.32,2.64$ and $4.01 \mathrm{~kJ} \mathrm{~m}^{-2}$, corresponding to the time intervals of $0,16,30,60$ and $91 \mathrm{~s}$, respectively. After irradiation, the figs were placed in open plastic trays containing eight figs each and stored at temperatures of $10 \pm 2{ }^{\circ} \mathrm{C}$ and $20 \pm 2{ }^{\circ} \mathrm{C}$ in a relative humidity of $90 \pm 5 \%$, for a period of seven days, and subjected to periodic quality assessments over the storage period. Evaluations of fig appearance were performed every two days and physico-chemical assessments such as weight loss, soluble solids content, titratable acidity and $\mathrm{pH}$, on the initial and final days.

Appearance was visually evaluated, based on a subjective scale of grades ranging from 0 to 10 , taking into account the percentage of the following attributes: (a) ripeness, based on the development of the epidermis' purplish coloration area; (b) wilting, based on the degree of surface wrinkling; (c) physical stains and damages, based on the amount of darker spots on the fruit epidermis caused by physical damage and UV radiation; and (d) rot, evaluated by the percentage of figs with fungal contamination in each package. For each of the above appearance attributes, the zero score corresponds to the absence of the attribute. The overall grade for appearance was used to calculate the Global Index (GI) corresponding to the sum of the average values of the appearance

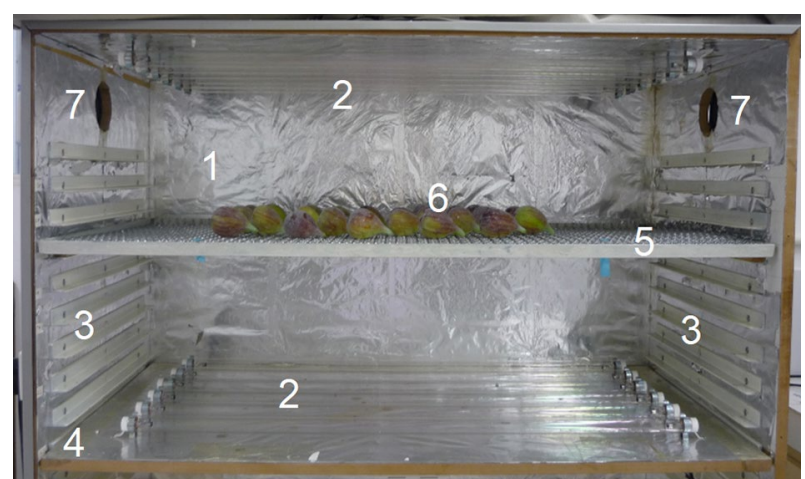

Figure 1 - Inside view of the chamber used for ultraviolet (UV-C) radiation in figs. 1 . Aluminum foil coating; 2 . UV lamps; 3 . Lateral supports; 4. Adjustable lower bottom; 5. Screened adjustable shelf; 6 . figs; 7. Side forced air exhaustion holes. attributes, with weighting two for dark spots, physical damages and rot and weighting one for the others.

Weight loss was calculated by the difference between the initial and final mass of figs in each package (0.01 g). Total Soluble solids (TSS) was determined according to the official methodology of the Association of Official Analytical Chemistry (2005), using a manual refractometer $\left(0.01^{\circ}\right.$ Brix). Titratable acidity (TA) was determined following the methodology of the AOAC (2005) by the titration of $10 \mathrm{~g}$ of comminuted pulp and homogenized with $90 \mathrm{~mL}$ of distilled water, using a standardized solution of $0.10 \mathrm{~N}$ sodium hydroxide $(\mathrm{NaOH})$ and a digital potentiometer and the results expressed as a percentage of citric acid.

A completely randomized $5 \times 2$ factorial design with five radiation levels $(0.00,0.71,1.32,2.64$ and 4.01 $\left.\mathrm{kJ} \mathrm{m}^{-2}\right)$ and two storage temperatures $\left(10^{\circ} \mathrm{C}\right.$ and $\left.20^{\circ} \mathrm{C}\right)$ was used. For the analysis of appearance and weight loss, five replicates were used, each repetition consisting of a pack of 8 figs, and the analysis of TSS, TA and $\mathrm{pH}$ were performed with five replicates, using one fig for each replicate. Thus, for each treatment, 40 figs and a total of 400 figs were used for each experiment, each experiment being performed in triplicate (1200 figs in total). The results were submitted to analysis of variance (ANOVA) and comparison of means between treatments (Tukey, $p<0.05$ ), with the aid of the SAS (Statistical Analysis System) statistical package, version 9.1.3.

\section{Results and Discussion}

The average results for weight loss, soluble solids content, titratable acidity and $\mathrm{pH}$, determined on the first and last day of the seven days storage period, are shown in Table 1.

The effect of UV radiation on weight loss at both temperatures for all treatments was not significant.

Table 1 - Mean values ( $n=15$ ) of total soluble solids (TSS), titratable acidity (TA), pH and weight loss on the initial and final days of storage for irradiated figs with different energy levels, stored at 10 ${ }^{\circ} \mathrm{C}$ and $20^{\circ} \mathrm{C}$ for seven days after the application of the radiation.

\begin{tabular}{|c|c|c|c|c|c|}
\hline${ }^{\mathrm{T}}{ }^{\circ} \mathrm{C}$ & $\begin{array}{l}\text { Energy } \\
\mathrm{kJ} \mathrm{m}^{-2}\end{array}$ & $\begin{array}{c}\text { TSS } \\
{ }^{\circ} \text { Brix Initial: } \\
11.23 \mathrm{~A}\end{array}$ & $\begin{array}{c}\text { TA } \\
\% \text { citric acid } \\
\text { Initial: } 0.20 \mathrm{~A}\end{array}$ & $\begin{array}{c}\mathrm{pH} \\
\text { Initial: } 4.92 \mathrm{~A}\end{array}$ & $\begin{array}{c}\text { Weight Loss } \\
\%\end{array}$ \\
\hline \multirow{5}{*}{10} & 0.00 & $11.59 \mathrm{Aa}$ & $0.21 \mathrm{Aa}$ & $5.31 \mathrm{Ba}$ & $6.37 \mathrm{a}$ \\
\hline & 0.71 & $11.81 \mathrm{Aa}$ & $0.17 \mathrm{Aa}$ & 5.50 Bab & $6.62 \mathrm{a}$ \\
\hline & 1.32 & $11.72 \mathrm{Aa}$ & $0.20 \mathrm{Aa}$ & $5.43 \mathrm{Bab}$ & $6.76 a$ \\
\hline & 2.64 & 12.02 Bab & $0.20 \mathrm{Aa}$ & 5.44 Bab & $7.04 \mathrm{a}$ \\
\hline & 4.01 & $11.63 \mathrm{Aa}$ & $0.20 \mathrm{Aa}$ & $5.18 \mathrm{Ba}$ & $7.08 \mathrm{a}$ \\
\hline \multirow{5}{*}{20} & 0.00 & $12.94 \mathrm{Bb}$ & $0.21 \mathrm{Aa}$ & $5.58 \mathrm{Bab}$ & $9.65 \mathrm{~b}$ \\
\hline & 0.71 & $11.51 \mathrm{Aa}$ & $0.19 \mathrm{Aa}$ & 5.45 Bab & $9.03 b$ \\
\hline & 1.32 & $11.57 \mathrm{Aa}$ & $0.19 \mathrm{Aa}$ & $5.70 \mathrm{Bb}$ & $9.72 b$ \\
\hline & 2.64 & $11.78 \mathrm{Aa}$ & $0.18 \mathrm{Aa}$ & $5.65 \mathrm{Bab}$ & $9.01 \mathrm{~b}$ \\
\hline & 4.01 & 12.11 Bab & $0.20 \mathrm{Aa}$ & 5.50 Bab & $9.46 \mathrm{~b}$ \\
\hline \multicolumn{2}{|c|}{ CV (\%) } & 4.18 & 11.71 & 1.93 & 5.64 \\
\hline
\end{tabular}

Means followed by the same capital letter in the row and lower case in the column do not differ $(p<0.05)$. CV $=$ coefficient of variation. 
However, mean values of total weight losses, close to $7 \%$ and $9 \%$, for treatments at $10^{\circ} \mathrm{C}$ and $20^{\circ} \mathrm{C}$, respectively, showed a significant effect attributable to temperature (Tukey, $p<0.05$ ) mostly due to the difference of vapor pressure between the two storage environments. Even though losses are expected under such conditions, average values above $3 \%$ are already noticeably affecting appearance and market value. Van Hung et al. (2011) observed losses of the same order of magnitude for figs exposed to UV-C radiation, for which there was no influence of radiation on weight loss.

There was a difference in TSS only for temperature levels and there was no significant interaction between TSS values and radiation levels. These results are in accordance with those obtained by Van Hung et al. (2011), in which fig storage at $95 \%$ of humidity and temperatures of 5.5 and $7{ }^{\circ} \mathrm{C}$ for 6,8 and 10 days, showed significant differences between storage days only. At a temperature of $20^{\circ} \mathrm{C}$, the control and radiation treatments of 4.01 $\mathrm{kJ} \mathrm{m}{ }^{-2}$ showed the highest averages (Table 1), but no significant tendency was observed. This increase in TTS mean values may be attributed to water loss, the main component of weight loss. However, since the TSS content was determined by taking whole figs, its values did not reflect the greater losses closer to the epidermis, and, consequently, a discrete variation was obtained in their values. Wilting values have the potential to provide evidence of this superficial effect of the weight loss. For TA (Table 1), no significant differences were observed between storage temperatures nor UV-C radiation. For $\mathrm{pH}$ (Table 1), there was a significant difference in irradiation levels as well as for storage temperatures. Higher $\mathrm{pH}$ values were observed in the control treatment at both $10{ }^{\circ} \mathrm{C}$ and $20{ }^{\circ} \mathrm{C}$ storage temperatures. Results of the physico-chemical analysis showed that none of the UV-C radiation levels affected fruit quality during the storage time considered.

Figures 2A, B, C and D show the average values of appearance ripening, wilting, stains, physical damages and rot appearance of figs exposed to UV-C radiation of $0.00,0.71,1.32,2.64$ and $4.01 \mathrm{~kJ} \mathrm{~m}^{-2}$ and stored at $10^{\circ} \mathrm{C}$ and $20^{\circ} \mathrm{C}$. The interaction between temperature and radiation was significant for the ripening, wilting and rot parameters, providing evidence of effects that varied across the treatments. Figs stored at $10{ }^{\circ} \mathrm{C}$ showed lower values for ripening, wilting, stains, physical damage and rot than for treatments at $20{ }^{\circ} \mathrm{C}$, providing evidence of the dominating effect of temperature on fruit quality maintenance. Figs exposed to radiation energy levels between $0.71 \mathrm{~kJ} \mathrm{~m}^{-2}$ and $4.01 \mathrm{~kJ} \mathrm{~m}^{-2}$ and stored at $20^{\circ} \mathrm{C}$ showed a lower incidence of rot, differing statistically from the control treatment, except for the energy reading of $1.32 \mathrm{~kJ} \mathrm{~m}^{-2}$. Figs exposed to the highest radiation level, $4.01 \mathrm{~kJ} \mathrm{~m}^{-2}$, showed more wilting, stains and physical damage, significantly impairing their appearance. Similar behavior was reported by Shama and Alderson (2005) for other fruit such as grapes, blueberries and strawberries, for which energy levels above $1.0 \mathrm{~kJ}$ $\mathrm{m}^{-2}$ caused epidermis darkening and quality loss, and by Ding and Yap (2014) and Ding et al. (2015), who observed that UV-C irradiation above $0.01 \mathrm{~kJ} \mathrm{~m}^{-2}$ causes peel browning in banana which affects the visual quality
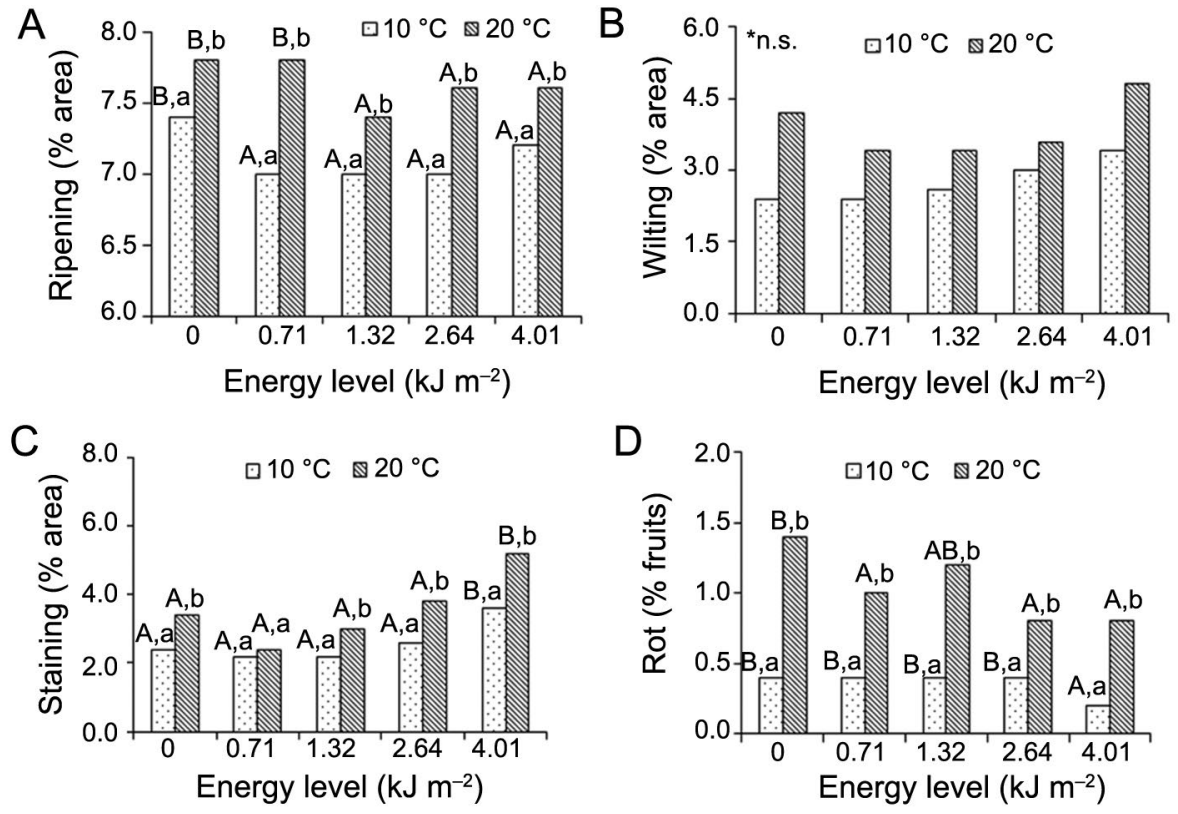

Figure 2 - Mean values of ripening (A), wilting (B), stains and physical damage $(C)$ and rot $(D)$ at the end of seven days of storage of figs submitted to different UV-C radiation energy levels and stored at $10{ }^{\circ} \mathrm{C}$ and $20^{\circ} \mathrm{C}$ (means followed by the same capital letter between energy levels and lower case between temperatures do not differ $(p<0.05))$. * $n$.s. $=$ not significant. 
of fruit. The initial ripening mean value, equal to five, increased to 7.12 and 7.64 , for temperatures of $10{ }^{\circ} \mathrm{C}$ and $20{ }^{\circ} \mathrm{C}$, respectively. As expected, due to the discrete fig climacteric behavior reported in the literature (Ryall and Pentzer, 1982), there was no significant change in coloration for either temperature. The energy levels applied neither accelerated nor delayed fig ripening (Figure 2A). Wilting was observed on the second and fourth days for temperatures of $20{ }^{\circ} \mathrm{C}$ and $10{ }^{\circ} \mathrm{C}$, respectively, and was higher at $20^{\circ} \mathrm{C}$, in agreement with the variations in weight loss.

The observations during the experiments suggest that the effect of UV-C radiation is not noticeable immediately after its application. They also suggest that increases in the number of spots and rot with storage time are associated with both the storage temperature and the UV radiation level (Table 2). Since the relationship between the presence of spots together with rot is an important indicator of the performance of UV radiation, in this experiment, the rot was observed only from days seven and five, at temperatures of $10{ }^{\circ} \mathrm{C}$ and $20{ }^{\circ} \mathrm{C}$, respectively, while the spots were observed on the second day for both treatments. Higher energy levels had higher values for spots and they appeared earlier during storage. The presence of stains and physical damage was consistently higher at $20{ }^{\circ} \mathrm{C}$, indicating an effect caused by temperature. On the seventh day, the efficacy of UV-C was demonstrated since radiation values above $0.70 \mathrm{~kJ} \mathrm{~m}^{-2}$, at $10{ }^{\circ} \mathrm{C}$, did not show any incidence of rot, and the incidence of rot at $20{ }^{\circ} \mathrm{C}$ was reduced by more than $50 \%$ as compared to the control for this temperature. In view of these results and to express these attributes in a single number a global index (GI) was proposed defined as the weighted sum of the mean values of ripening, wilting, stains and physical damage and rot, with weighting value two for ripening and wilting and weighting value 1 for the others, divided by the sum of the weightings (6). The GI, because of the greater weighting values assigned to stains and physical damage and rot, expresses with greater emphasis both the effects of UV-C radiation, either deleterious, by the early appearance of stains and physical damage,

Table 2 - Variance Analysis of the appearance parameter "rot" of figs subjected to UV-C radiation of $0.00 \mathrm{~kJ} \mathrm{~m}^{-2}, 0.71 \mathrm{~kJ} \mathrm{~m}^{-2}, 1.32$ $\mathrm{kJ} \mathrm{m}^{-2}, 2.64 \mathrm{~kJ} \mathrm{~m}^{-2}$ and $4.01 \mathrm{~kJ} \mathrm{~m}^{-2}$, stored at $10{ }^{\circ} \mathrm{C}$ and $20{ }^{\circ} \mathrm{C}$ for seven days.

\begin{tabular}{lccccc}
\hline Source of Var. & df & SS & MS & $F$ & $P r>F$ \\
\hline Temperature & 1 & 528.1250 & 528.1250 & 9.94 & 0.0031 \\
Radiation & 4 & 606.2500 & 151.5625 & 2.85 & 0.0359 \\
Temperature $\times$ Radiation & 4 & 143.7500 & 35.9375 & 0.68 & 0.6123 \\
Error & 40 & 2125.0000 & 53.1250 & \\
Corrected Total & 49 & & & \\
\hline Mean & 4.75 & & \\
CV (\%) & 153.44 \\
$\mathrm{~N}$ & 50 \\
\hline df = degrees of freedom; SS = sum of squares; $\mathrm{MS}=$ mean square; $\mathrm{Pr}=$ \\
probability; CV = coefficient of variation.
\end{tabular}

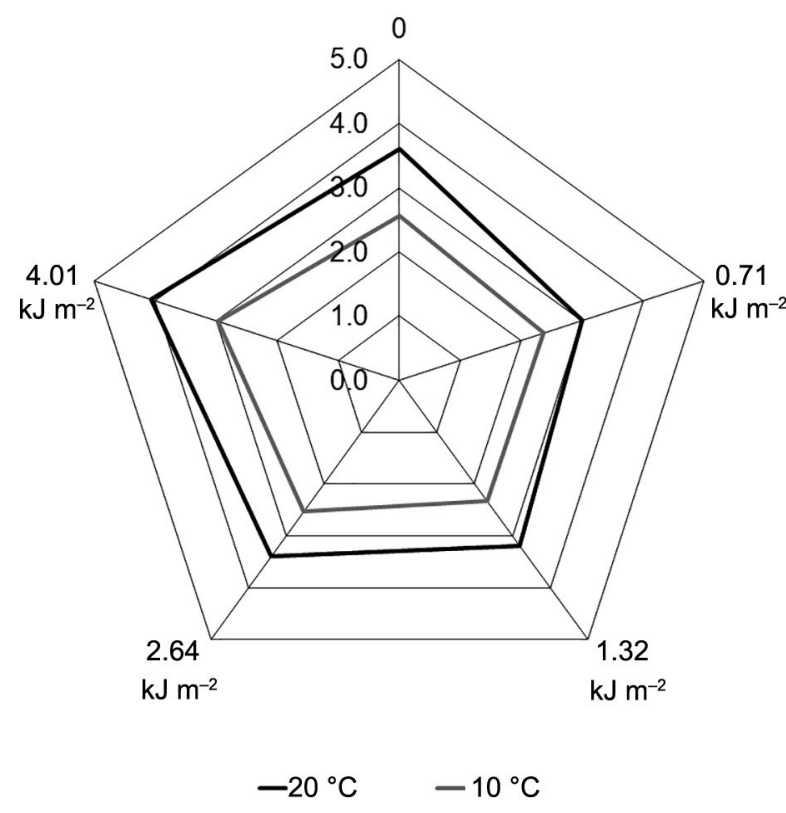

Figure 3 - Global Index (Gl) variation for figs submitted to different UV-C radiation energy levels, after seven days of storage at $10^{\circ} \mathrm{C}$ and $20^{\circ} \mathrm{C}$

or beneficial, by delaying rot manifestation. Increasing GI values represent increasing losses in quality. The results, for both temperatures, are shown in Figure 3. In addition to showing the temperature dependence, already identified in the previous analysis, by the higher GI values obtained at $20^{\circ} \mathrm{C}$ than those at $10{ }^{\circ} \mathrm{C}$, the 0.0 $\mathrm{kJ} \mathrm{m}{ }^{-2}, 0.71 \mathrm{~kJ} \mathrm{~m}^{-2}$ and $1.32 \mathrm{~kJ} \mathrm{~m}^{-2}$ treatments showed similar linear behavior until the fifth day, differing on the sixth day, especially from control values. The $2.64 \mathrm{~kJ}$ $\mathrm{m}^{-2}$ and $4.01 \mathrm{~kJ} \mathrm{~m}^{-2}$ treatments showed similar behavior at both temperatures, differing from the others by the highest GI values until the fifth day and, on the seventh day, significantly lower values than the controls. The GI values were lower, in most cases, for the $0.71 \mathrm{~kJ} \mathrm{~m}^{-2}$ and $1.32 \mathrm{~kJ} \mathrm{~m}^{-2}$ treatments at the temperatures of $20^{\circ} \mathrm{C}$ and $10{ }^{\circ} \mathrm{C}$, respectively.

\section{Conclusion}

UV-C radiation of $2.64 \mathrm{~kJ} \mathrm{~m}^{-2}$ and $4.01 \mathrm{~kJ} \mathrm{~m}^{-2}$ reduces rotting development, providing evidence of its potential in the postharvest processing of ripe figs. However, radiation levels should be limited to avoid undesirable dark spots on the epidermis.

\section{Authors' Contributions}

Conceptualization: Usberti, F.C.S.; Ferraz, A.C.O. Data acquisition: Usberti, F.C.S. Data analysis: Usberti, F.C.S.; Ferraz, A.C.O. Design of methodology: Usberti, F.C.S. Writing and editing: Usberti, F.C.S.; Ferraz, A.C.O. 


\section{References}

Aday, M.S.; Temizkan, R.; Büyükcan, M.B.; Caner, C. 2013. An innovative technique for extending shelf life of strawberry: ultrasound. Food Science and Technology 52: 93-101.

Association of Official Analytical Chemists- International [AOAC]. 2005. Official Methods of Analysis. 18ed. AOAC, Gaithersburg, MD, USA.

Bermúdez-Aguirre, D.; Barbosa-Cánovas, G.V. 2013. Disinfection of selected vegetables under nonthermal treatments: chlorine, acid citric, ultraviolet light and ozone. Food Control 29: 82-90.

Coelho, C.C.S.; Freitas-Silva, O.; Campos, R.S.; Bezerra, V.S.; Cabral, L.M.C. 2015. Ozonation as post-harvest technology in conservation of fruits and vegetables: a review. Revista Brasileira de Engenharia Agrícola e Ambiental 19: 369-375 (in Portuguese, with abstract in English).

Ding, P.; Yap, S.L. 2014. Browning assessment methods and polyphenol oxidase in UV-C irradiated Berangan banana fruit. International Food Research Journal 21: 1667-1674.

Ding, P.; Muhammad Firdaus, R.; Nur Ayuni, M. 2015. UV-C irradiation affects quality, antioxidant compounds and activity of Musa AAA Berangan. Sains Malaysiana 44: 1095-1101.

Franz, C.M.A.P.; Specht, I.; Cho, G.S.; Graef, V.; Stahl, M.R. 2009. UV-C-inactivation of microorganisms in naturally cloudy apple juice using novel inactivation equipment based on Dean vortex technology. Food Control 20: 1103-1107.

Ge, C.; Bohrerova, Z.; Lee, J. 2013. Inactivation of internalized Salmonella Typhimurium in lettuce and green onion using ultraviolet C irradiation and chemical sanitizers. Journal of Applied Microbiology 114: 1415-1424.

Klinder, A.; Shen, Q.; Heppel, S.; Lovegrove, J.A.; Rowlanda, I.; Tuohyac, K.M. 2016. Impact of increasing fruit and vegetables and flavonoid intake on the human gut microbiota. Food Funct 7: 1788-1796.

Manzocco, L.; Pieve, S.; Bertolini, A.; Bartolomeoli, I.; Maifreni, M.; Vianello, A.; Nicoli, M.C. 2011. Surface decontamination of fresh-cut apple by UV-C light exposure: effects on structure, colour and sensory properties. Postharvest Biology and Technology 61: 165-171.
Pombo, M.A.; Dotto, M.C.; Martinez, G.A.; Civello, P.M. 2009. UV-C irradiation delays strawberry fruit softening and modifies the expression of genes involved in cell wall degradation. Postharvest Biology and Technology 51: 141-148.

Ryall, A.; Pentzer, W.T. 1982. Handling, Transportation and Storage of Fruits and Vegetables. 2ed. Saybrook Press, Pasadena, CA, USA.

São José, J.F.B.; Andrade, N.J.; Ramos, A.M.; Vanetti, M.C.D.; Stringheta, P.C.; Chaves, J.B.P. 2014. Decontamination by ultrasound application in fresh fruits and vegetables. Food Control 45: 36-50.

Savi, G.D.; Piacentini, K.C.; Bittencourt, K.O.; Scussel, V.M. 2014. Ozone treatment efficiency on Fusarium graminearum and deoxynivalenol degradation and its effects on whole wheat grains (Triticum aestivum L.) quality and germination. Journal of Stored Products Research 59: 245-253.

Shama, G.; Alderson, P. 2005. UV hormesis in fruits: a concept ripe for commercialization. Trends in Food Science \& Technology 16: 128-136.

Tureck, C.; Locateli, G.; Corrêa, V.G.; Koehnlein, E.A. 2017. Evaluation of the Brazilian population's intake of antioxidant nutrients and their relation with the nutritional status. Revista Brasileira de Epidemiologia 20: 30-42.

Van Hung, D.; Tong, S.; Tanaka, F.; Yasunaga, E.; Hamanaka, D.; Hiruma, N.; Uchino, T. 2011. Controlling the weight loss of fresh produce during postharvest storage under a nano-sized mist environment. Journal of Food Engineering 106: 325-330.

Wadamori, Y.; Gooneratne, R.; Hussain, M.A. 2017. Outbreaks and factors influencing microbiological contamination of fresh produce. Science of Food and Agriculture 97: 1396-1403.

Yaun, B.S.; Sumner, S.S.; Eifert, J.D.; Marcy, J.E. 2004. Inhibition of pathogens on fresh produce by ultraviolet energy. International Journal of Food Microbiology 90: 1-8.

Zhu, Q.; Gooneratne, R.; Hussain, M.A. 2017. Listeria monocytogenes in Fresh Produce: Outbreaks, Prevalence and Contamination Levels. Foods 6: 21. 